\title{
OR1G1 Gene
}

National Cancer Institute

\section{Source}

National Cancer Institute. OR1G1 Gene. NCI Thesaurus. Code C24650.

This gene plays a role in olfactory perception and modulation. 